\title{
Learning Nonfiction in an ESL Class: The Interaction of Situated Practice and Teacher Scaffolding in a Genre Study
}

Jason Ranker

A first-grade ESL teacher used a complex combination of both expert guidance and collaborative experiences when exploring nonfiction with her class.

$\mathrm{T}$ he teaching and learning of various genres has become an important topic in literacy education, and several aspects of genre studies in literacy classrooms have recently been explored (Dean, 2008; Duke \& Purcell-Gates, 2003; Palmer \& Stewart, 2005; Read, 2005). Researchers have examined young students' learning of fictional genres (e.g., poetry, short story, novel), nonfiction (e.g., informational, memoir, essay), and media genres (e.g., webpages, television formats, advertisements, video games), among others. Many educators agree that students need to have the ability to read and write within various genres to participate successfully at school and in other social spaces where these genres are valued.

Although many educators agree that facility with multiple genres is essential for students' literacy learning, there has been healthy debate regarding how to go about teaching genres. On the one hand, genre theorists and researchers have emphasized that genre elements need to be taught or explained overtly to students, with teachers (as experts) drawing attention to conventional ways of writing within a genre (Christie, 1985; Cope \& Kalantzis, 1993). From this perspective, only through such expert guidance will students-particularly students for whom schoolbased genres do not match up with genres used in the home-have access to the socially powerful and valued ways of using genres.

On the other hand, some literacy scholars have argued that overly explicit teaching of genre elements can become reductionistic, formulaic, or unquestioningly reinforcing of dominant cultural practices (Green, 1987; Sawyer \& Watson, 1989). By treating a genre as a fixed entity, students may get the impression that a genre is a recipe for writing texts, and that there is only one right way of reading and writing texts within a particular genre. In addition, Kress (1993) noted that genres are not only sets of elements or text types. Rather, he argued, genres are purposeful, social, and lived out in actual communities. From this perspective, genres are not fixed but rather change over time and from one social context to another (Miller, 1994). Learning a new genre thus requires participation in a community of others with whom the genre is used to communicate and extended opportunities to actually read, write, and speak within the genre.

So how does one learn to read and write in a new genre? Through instruction from the teacher? Or from extended and collaborative experiences with reading and writing texts within the genre? According to literacy and learning researchers, the answer may involve a complex combination of both elements in one's genre teaching (Hicks, 1997; New London Group, 2000). In this article, I invite you to look in depth into Ms. Stevens's (a pseudonym, as are all proper names in this article) first-grade classroom to consider this important teaching question. The students in this urban, public, ESL classroom engaged in a nonfiction genre study using the theme of 
animals. Ms. Stevens provided the students with expert guidance and opportunities to conduct research and write their own books about animals. I studied Ms. Stevens's implementation of this curricular unit to consider the importance of her expert guidance on the one hand-and the students' more open-ended opportunities to read and write within the genre, on the other-in the students' learning processes.

This teaching question about the relative roles of instruction and extended practice also has an important place in discussions of the learning of additional language literacies (Christie, 1999; Gibbons, 2002). Literacy researchers, for example, have drawn attention to how extended composing and reading practice, purposeful uses of texts, and opportunities to use the new language in ways that are open-ended and communicative are key to learning additional language literacies or biliteracies (Fu, 2003; Gutiérrez, 1992; Samway, 2006). On the other hand, literacy researchers have drawn attention to the importance of overt guidance, or scaffolding students as they learn new genres (Gibbons, 2002) and other literacies (Boyle \& Peregoy, 1990). Drawing upon Wood, Bruner, and Ross's (1976) idea of scaffolding and Vygotskian (Vygotsky, 1978) ideas of development, Gibbons (2002) defined scaffolding as "temporary assistance by which a teacher helps a learner know how to do something so that the learner will later be able to complete a similar task alone" (p. 10).

During my case study of Ms. Stevens's classroom, I paid particular attention to how two aspects of the teaching and learning environments interacted during the focal genre study: overt instruction, or "active interventions on the part of the teacher...that scaffold learning activities" (New London Group, 2000, p. 33), and situated practice, or "immersion in meaningful practices within a community of learners" (p. 33). The term overt instruction resonates with, but is distinct from, such terms as direct instruction and explicit teaching and "does not imply direct transmission, drills, and rote memorization" (p. 33). In the teaching of writing, overt instruction emphasizes the teacher drawing students' attention to particular aspects of literacy learning through lessons, writing conferences, small groups, and other discussions with the students as they work on their own writing.

Situated practice refers to students' active and collaborative engagement in the actual activity being learned (reading or writing extended texts within a particular genre, in this case). This involves, for example, more open-ended activities such as composing a text or reading a book within the genre. Situated practice provides opportunities for students to try out what the teacher demonstrates through overt instruction, along with having some choice and opportunity to invest their own meaning into the activity within a collaborative social context. Without situated practice, according to this definition, the students do not have an opportunity to use, actually learn, or apply what the teacher offers through overt instruction.

In this article, I demonstrate how Ms. Stevens's overt exploration of nonfiction with the students was coupled with extended opportunities for the students to explore nonfiction and produce their own nonfiction texts (or situated practice with reading and writing nonfiction). By exploring situated practice and overt instruction as I did, readers can consider how this case study can inform their own genre teaching.

\section{Background of the Study}

This article is based on a larger study of the literacy practices in the focal classroom over a period of seven months. During this study, I visited the focal classroom once or twice each week during the reading and writing workshops (Avery, 2002; Taberski, 2000) that Ms. Stevens implemented. Her workshops included the following elements: a lesson connected to a read-aloud; an extended period for students to read and write texts that they chose (as she conducted individual conferences or small writing groups); and a whole-class sharing time during which students would discuss their writing or reading on that day. Periodically, Ms. Stevens conducted genre studies that used the same basic format of the workshop but focused on one particular genre (such as poetry, comic books, or the nonfiction study that I discuss in this article), as workshop advocates have described (Atwell, 1998; Calkins, 1994).

Using qualitative case-study research methods (Dyson \& Genishi, 2005; Merriam, 1998), I gathered and analyzed the following types of data to understand the classroom literacy practices: video/audio recordings of the reading and writing events; video/ audio recordings of Ms. Stevens's lessons; photocopies of all of the students' writing; audiorecorded, informal discussions with Ms. Stevens and the students; 
and field notes. I analyzed the students' writing and composing processes across time to explore how the students used elements of Ms. Stevens's lessons as tools, of sorts, in their situated literacy practices.

The students in the study were $6-7$ years old, and they were in first grade. The students were bilingual (Spanish and English) and classified as English-language learners (ELLs), according to district language policies. The students had familial ties to the Dominican Republic, Guatemala, and Puerto Rico. One student in the class had moved to the school from Somalia during the school year. The students were at many various developmental points in their literacies in both languages, and most were quite competent with spoken English. For many students, English was used at home as well as Spanish. Ms. Stevens delivered instruction primarily in English, as mandated by district policies. However, Ms. Stevens did value the students' uses of Spanish and allowed the students to use Spanish when they needed to or chose to, despite this language restrictive policy to which her own instruction was subject.

\section{Introduction to the Nonfiction Genre Study About Animals}

Ms. Stevens designed a nonfiction genre study that incorporated a whole-class inquiry on frogs into her lessons. As the class conducted this inquiry over a period of three weeks, they researched and wrote their own whole-class big book about frogs. Ms. Stevens used her reading lessons to demonstrate research and text construction, using the class's emerging findings and published children's books about frogs as the instructional materials. This whole-class book also served as an example for the students as they researched and wrote their own books on various animals.

During the genre study, Ms. Stevens began the reading workshop with a read-aloud and its corresponding lesson. She read only from a text set of nonfiction books about frogs, demonstrating for the students how to access information to create the whole-class book about frogs. She focused on one area of frog life each day, eventually exploring several areas with the class, including physical appearance and interesting facts about frogs, their habitats, and their food. Through these lessons, she introduced the students to many elements and purposes of nonfiction.

Along with this overt instruction about nonfiction, Ms. Stevens provided extended periods of situated practice for the students to create their own texts. She did this by incorporating aspects of the daily reading and writing workshop structures into the genre study. She gave the students longer amounts of time to read books about animals. However, she structured the direction of the students' writing more specifically than usual by guiding the students toward writing their own nonfiction books about animals. In small groups, students wrote about tigers, lions, dogs, cats, spiders, monkeys, dolphins, and cheetahs.

To give a specific example of how Ms. Stevens implemented this genre study (as a way of considering the roles of overt instruction and situated practice in the students' genre learning), I describe one of her lessons in detail in the next section. Then, I feature an example of the students' situated practice reading and writing about sharks and their final text about sharks. Finally, I show an example of how some students transformed the practices that they learned during the genre study by applying them to their more open-ended writing practices after the genre study had ended.

\section{Overt Instruction: Whole-Class Big Book About Frogs}

The lesson that I discuss here took place while the class was working on the section for their class book about frogs' diet. Ms. Stevens began the lesson by rereading out loud with the students what they had written so far in their class big book. Then, she initiated a focused student reading period so that she could use the students' own research processes and findings as part of the emerging lesson. She set up the students' reading task as follows:

Let's move on to today's research. Today we are going to read about what frogs eat. I know some of you already have ideas about what frogs eat, but today we really need to support our information with the information in our books. Today, I want you to find information in your book about what frogs eat and maybe even how they eat. I remember that we talked about this when we were looking at their tongues earlier. So, every time that you find information about what a frog eats and how a frog eats, I want you to put a yellow sticky note on that page and make a note on it. 
Students then read together in small groups for approximately 20 minutes. After this time, Ms. Stevens called the students back to the whole-class meeting area and called on them to share what they had found. Several students contributed ideas and showed where they had found the information. With each proposed idea for the class book, Ms. Stevens helped the students to verify the information as she reread the found section back to the whole class. Processes such as these were central to the students' learning about nonfiction as a genre.

After this discussion, the next step was to construct a sentence based on each particular finding brought forth by a student. In the discussion below, Gabriela presents her finding from a children's book called Where Do Frogs Come From? (Vern, 2001). Bernard presents his finding about what frogs eat, drawn from All About Frogs (Arnosky, 2002).

Ms. Stevens: Who can tell me what information you found today about what frogs eat or how they eat? Gabriela? You can use what you wrote on your sticky note to help you.

Gabriela: They eat bugs.

Ms. Stevens: So frogs eat bugs. Did you get any information about what kind of bugs? No? That's OK. Gabriela gave us some information. She said, "Frogs eat bugs." Can anyone else tell us more information about what kinds of bugs frogs eat? Let's see, Bernard?

Bernard: $\quad$ Here [holds up All About Frogs].

Ms. Stevens: Oh, that's not a bug is it? It's a worm! So I think that we'll have to write two sentences-one about frogs eating bugs and another about frogs eating worms. Can you put that into a sentence for me, Louis, about frogs eating worms? What could we say?

Louis: $\quad$ Frogs like to eat worms.

The class then went on to discuss what kinds of frogs like to eat worms, discovering that primarily bullfrogs eat worms. The students then decided to write, "Some frogs eat worms." Figure 1 represents this sentence and the other sentences that the class generated from this discussion. Ms. Stevens also demonstrated details about sentence construction,
Figure 1

Sentence Strips From Whole-Class Lesson

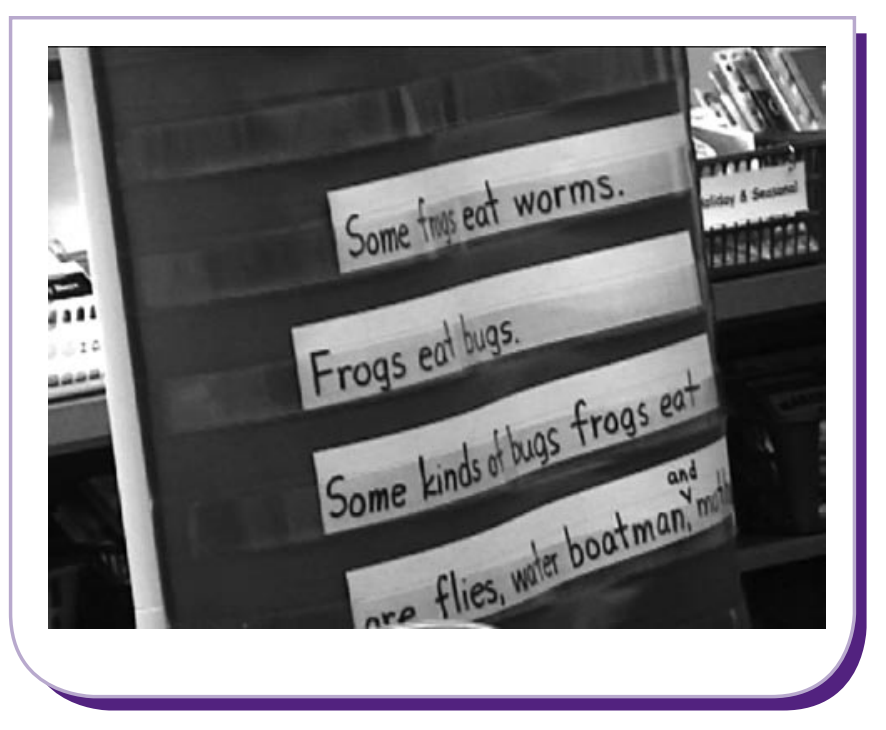

punctuation, spelling, and use of conjunctions within sentences as part of this process.

The next phase of Ms. Stevens's lesson involved ordering the sentences that they had created, using a pocket chart to discuss possible sequences and the rationales for which one worked the best. To introduce this section of the lesson, Ms. Stevens said,

So we found our information, we put it into sentences, and now we have to figure out what the best order of our sentences is. Because yesterday when we researched what frogs look like, we decided that maybe we should put all of the information about things that are on its head together, and all the information about its legs together. So let's look at our information and see if we might organize anything differently.

Then together the class members read aloud what they had written. As a few students came up and made suggestions for ordering, Ms. Stevens discussed the importance of not breaking up the long sentences that went onto two sentence strips. The class also came to the consensus that putting all of the sentences about what frogs eat together and all of the sentences about how frogs eat together made sense. The class also discussed which topic area should come first. After a bit of discussion, the class decided that the information about what frogs eat should come first. After the final version of the text was decided, Ms. Stevens transferred it into the class book. 
In this section I have focused on an example of Ms. Stevens's overt instruction, which provided the students with several possible writing tools to use in their own reading and writing practices. These writing tools, or lesson elements, included using a book to gather information for writing, locating a specific type of information, marking information for later use, verifying information, constructing sentences, ordering sentences, summarizing findings, and identifying and organizing themes in texts. In the next section, I feature the students' situated practice with reading and writing informational texts to demonstrate how the students put these writing tools to use in a meaningful, purposeful, and social context.

\section{Situated Practice: Researching and Writing About Sharks}

In this section, I discuss one of the students' collaborative research sessions when they read books about sharks in search of information that they might use in creating their own book about sharks. Each day, Ms. Stevens gave the students approximately 30 minutes to work on their own books about animals. During their situated practice with research and writing, the students used the overt instruction that Ms. Stevens had offered in her lessons associated with the class book about frogs. In other words, the students took up this information and applied it to their own collaborative work, even when Ms. Stevens was not immediately present. Further, situated practice became the means by which students put overt instruction to work.

In this example, four students (Juan, Julio, Yesenia, and Adriana) were focusing their research on the topic of where sharks live, as Ms. Stevens had asked the students to do after her lesson about where frogs live. The students read through a text set of 10 nonfiction books about sharks. The other research groups read text sets about the different animals that they were researching. As demonstrated during the lessons, the students found sections in the texts that addressed the topic of sharks' habitats, marking relevant pages with a sticky note so as to later transfer the idea to a sentence strip. These sentence strips were later used to construct the final text that the students would submit for the page in their own book.

As students read through the books in search of information about where sharks live, they discussed their emerging findings. In the discussion below, Julio draws attention to his finding as he read Sharks! (Betz, 2005). Yesenia and Adriana also found information about sharks' habitats as they read I Am a Shark (Stille, 2005).

Julio: Ooh, I found one.

Juan: Come on. Let's keep working. Let's keep working.

Yesenia: No, they live here.

Adriana: In the water.

Yesenia: They live in the ocean, between the fish.

As they read, they marked pages and began to write their information on sentence strips. The students did some work alone. At other times, the students discussed the legitimacy of their findings and whether they should use the found information on their page about where sharks live. The students used several reading strategies. They used pictures to find pages with information about where sharks live and then read through the text on the basis of what they saw in the picture. Students also scanned for the word live on pages that looked promising and then attempted to read the text in more detail.

The top half of Figure 2 shows the four sentences that the students selected to include on the page of their book about where sharks live. The sentences represent a mixture of language that reflected the students' speech and the academic language of the books that they were reading. The markings on the sentence strips reflect Ms. Stevens's individualized teaching with this group as she worked with them on ordering and editing the sentences. The bottom half of Figure 2 shows the students' chosen sentences from the day when they researched what sharks eat.

Figure 3 features the cover and table of contents of the students' final piece, "The Shark Book," the product of several days of situated practice with research and writing. This book took on the same format as the class's big book about frogs, which scaffolded the students during their situated practice, giving them purpose and direction in learning the genre of nonfiction. Figure 4 includes two pages from their final sharks book that addressed the topics (from top to bottom) of "where sharks live" and "what sharks eat." The top page reads "Sharks live in oceans. They live as far down as 2,500 feet deep. The 
Figure 2

Sentence Strips From the Students' Research About Sharks

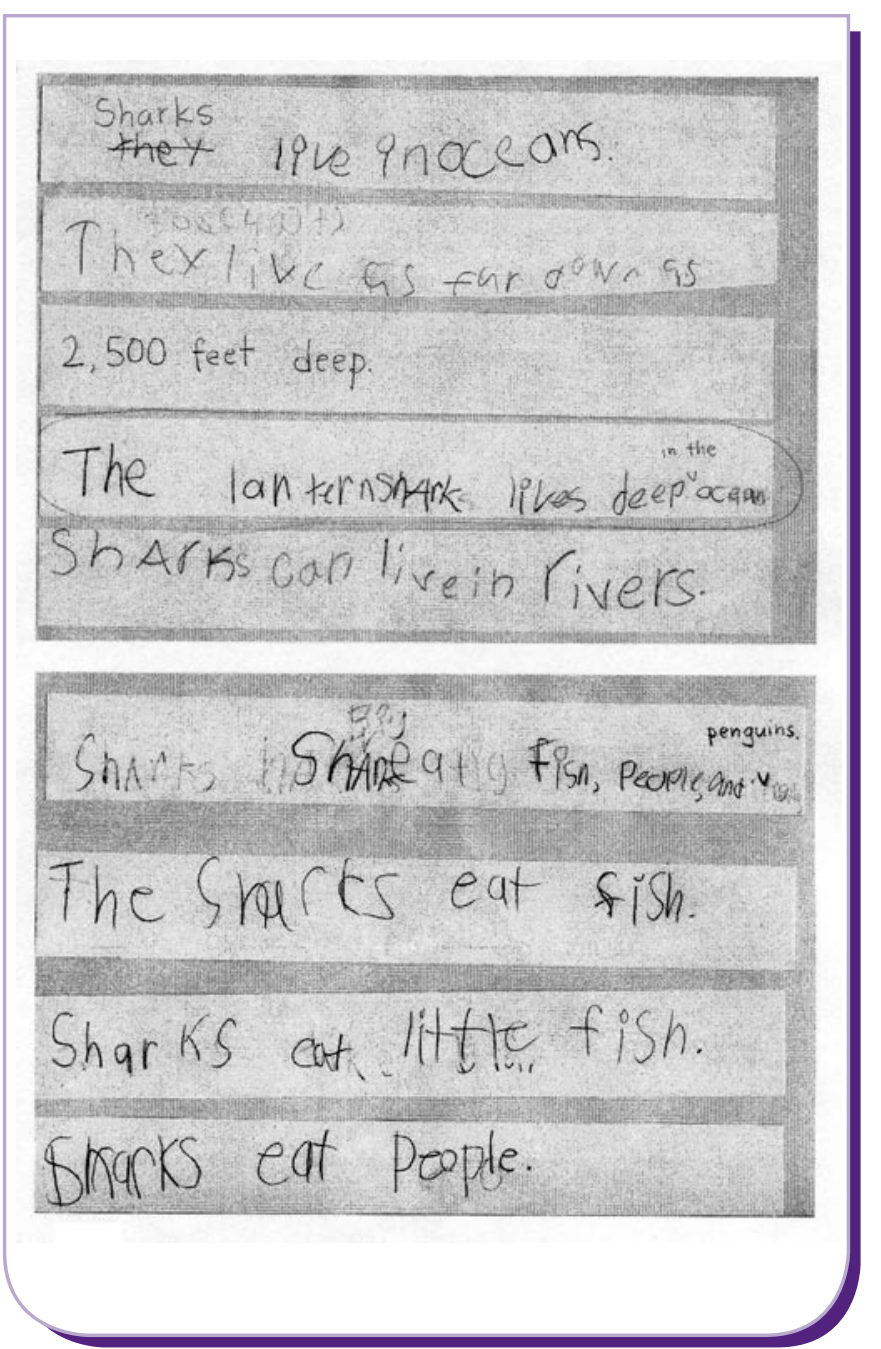

lantern shark lives deep in the ocean. Sharks can live in rivers." The bottom page reads, "Sharks eat fish, people, and seals. The sharks eat fish. Sharks eat little fish. Sharks eat people. Sharks eat little people, too." As the students composed this text, they drew upon several tools from Ms. Stevens's overt instruction, putting them to work in a meaningful and purposeful way during situated practice: using a book to gather information for writing, locating a specific type of information, marking information for later use, verifying information, constructing sentences, ordering sentences, summarizing findings, and identifying and organizing themes in texts.
Figure 3

Cover and Table of Contents From the Students' Book About Sharks

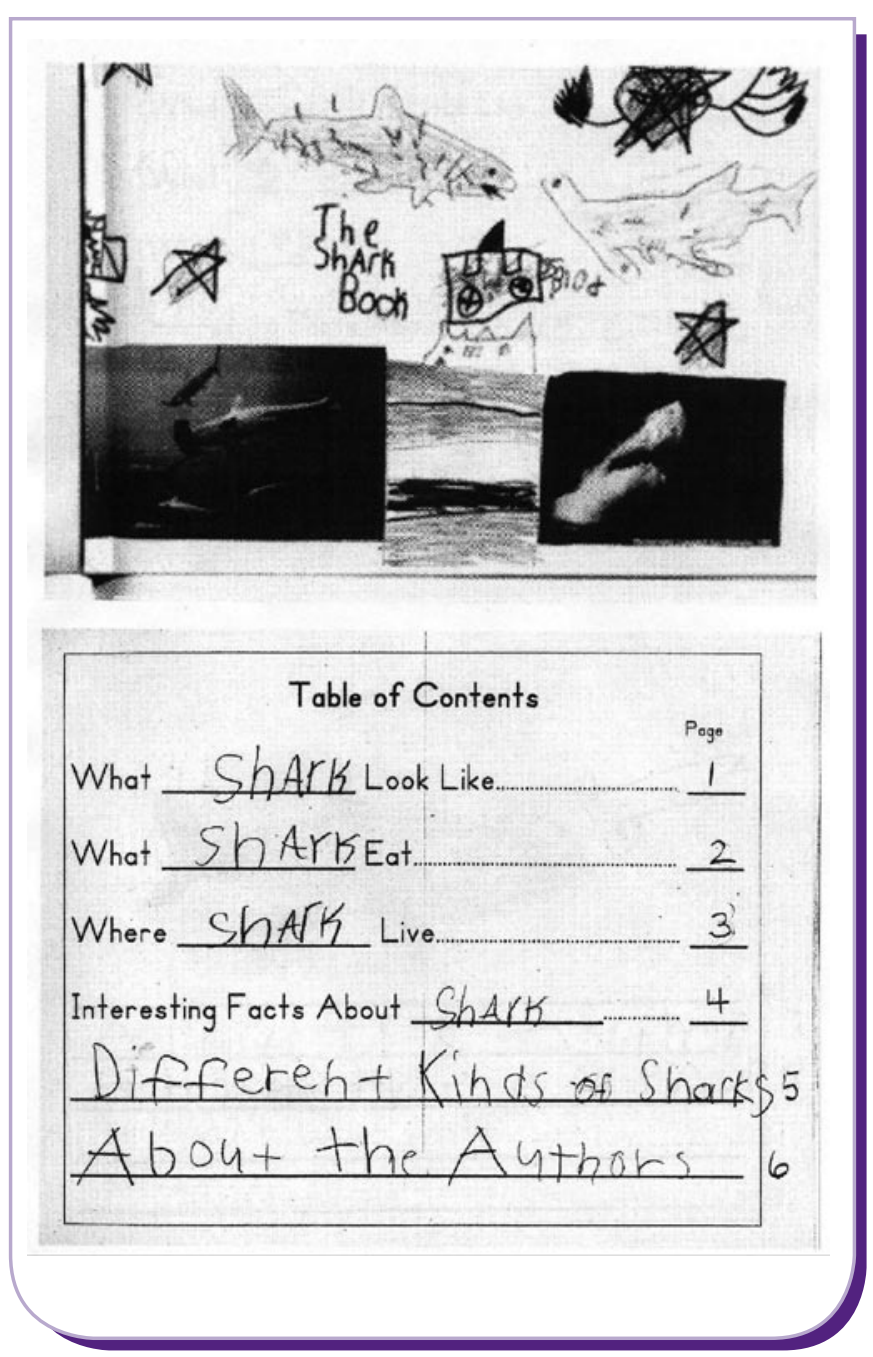

\section{Applying Nonfiction Literacy Practices to New Contexts}

Interestingly, some students continued to use books to locate content for their own writing after the genre study had ended and the daily writing workshop had resumed. Three students, Julio, Juan, and Robert, did so as they composed a multipage text they called "The Titanic." Each of the boys contributed pages to the composition, discussing their ideas with one another while composing. Figure 5 is a reproduction of three pages of their writing. From top to bottom, they read: "The boat goes fast; [the Titanic] is stuck; and [The Titanic] is sinking." 
Figure 4

Two Sample Pages From the Students' Book About Sharks

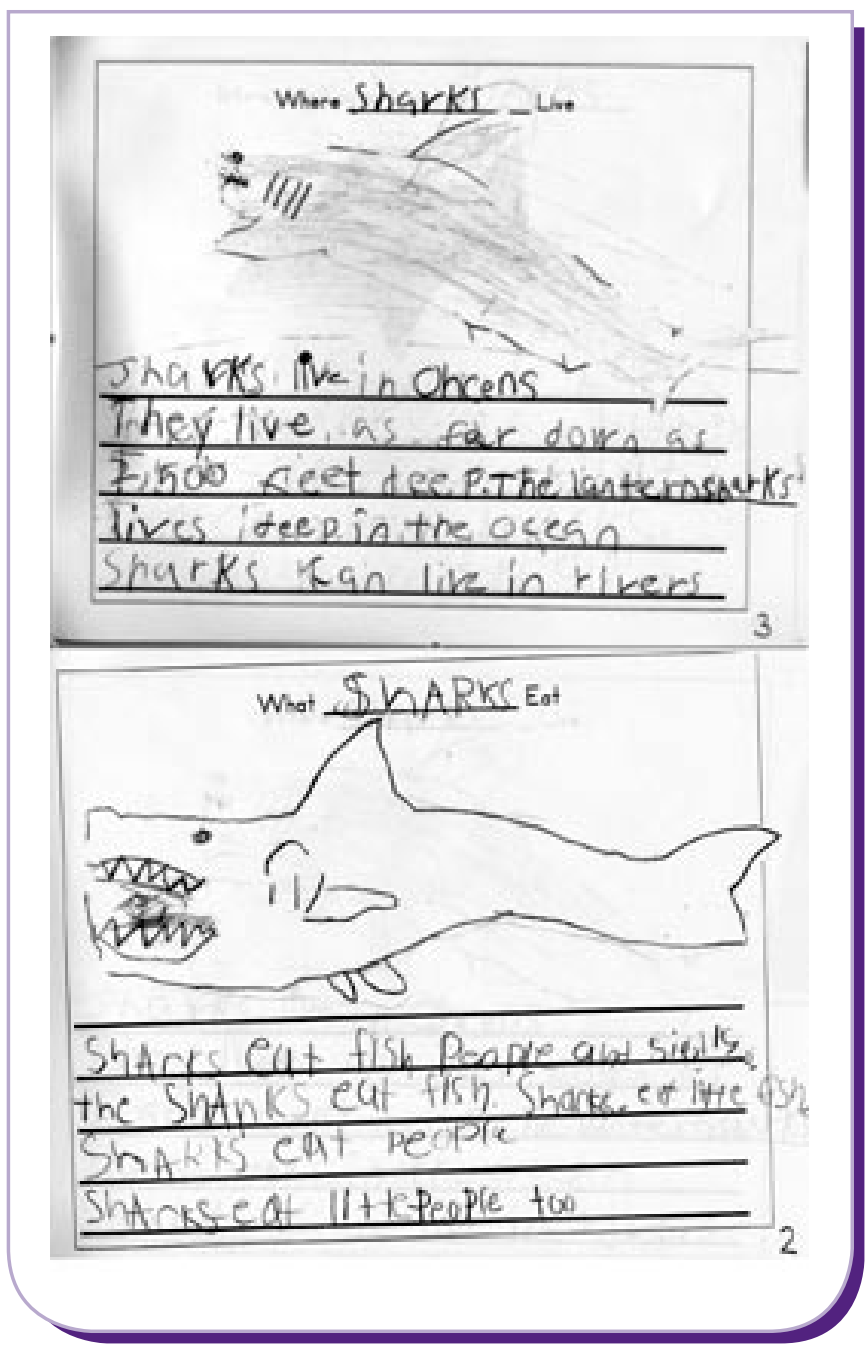

During this event, the students used a published children's book, Inside the Titanic (Marschall, 1997), which Julio had checked out at the school library, as a source of information for content. While writing, the boys looked at the book together and used it for ideas about what to write and draw. Ms. Stevens explained how the boys' decision to write about the Titanic was influenced by the nonfiction genre study that the class had engaged in recently. She noted,

One of the boys got a book about the Titanic from the school library. After we finished writing our nonfiction animal reports, I introduced some other types of informational books and invited them to write other types of informational books if they wanted to. That group
Figure 5

Three Sample Pages From the Students' Composition, "The Titanic"

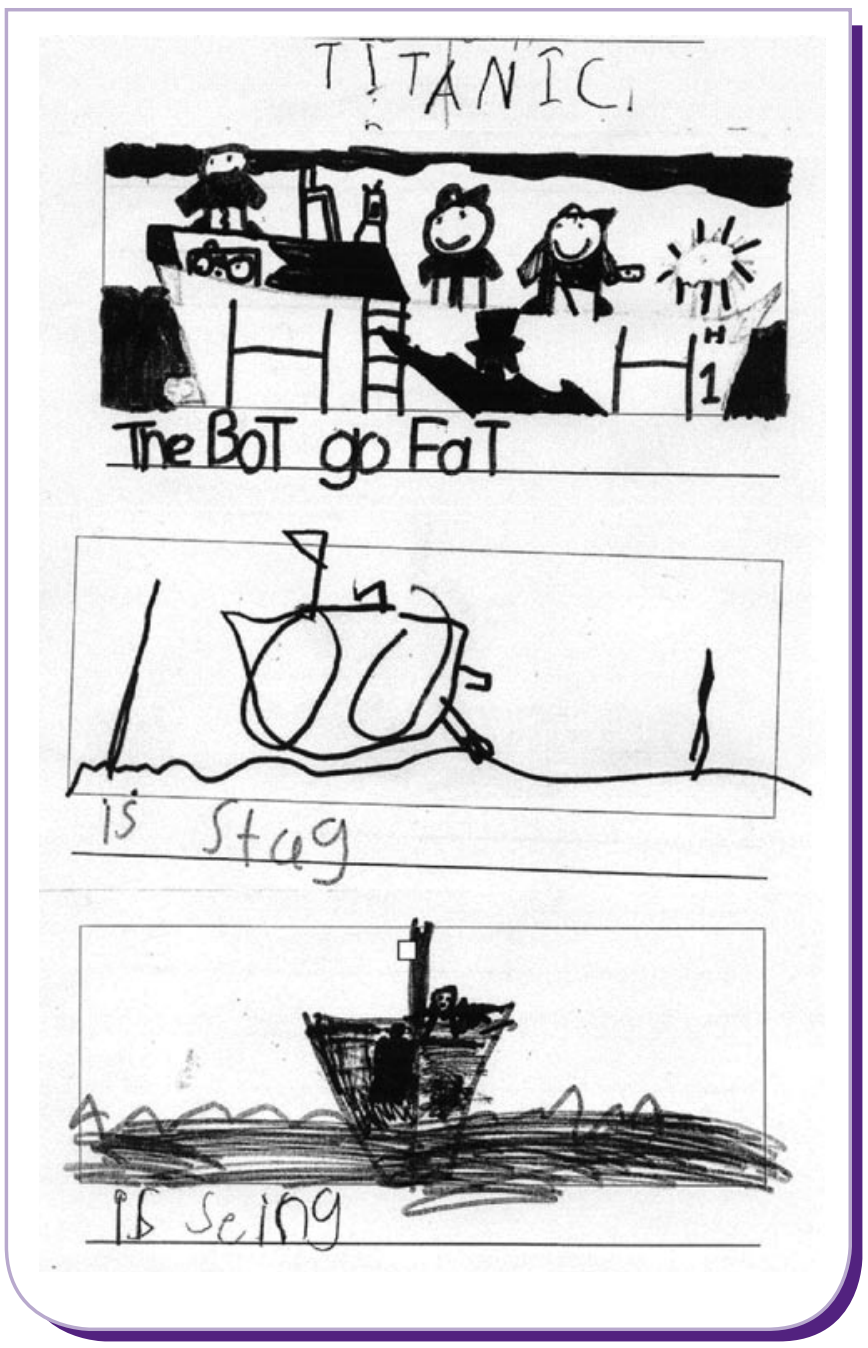

of boys realized that the Titanic disaster was a real, historical event and decided to write about it.

Below is an excerpt of the transcript that typifies the way in which they boys used the nonfiction book about the Titanic as they composed:

Juan: Look it. Look it [referring to a picture of the Titanic hitting an iceberg].

Julio: Yeah, they hit that.

Juan: Look it. You see that? That's what happened. And the wind brought it and people died.

Julio: That's what happened on the Titanic: a big ice. And I saw it. And they hit it really hard. And it broke-see? 
Robert: Let me look at this.

Julio: They're drowning.

Juan: Look at this!

Julio: Here, Juan. Look, Juan. See-it broke in pieces! It broke in pieces! Write the Titanic was strong. It's made out of metal. The Titanic was made out of metal. No, just write: The Titanic was made from metal.

The way that the students used the book about the Titanic resembled how they had used books during the genre study. This event provides another example of how writing tools from previous days' lessons, in addition to the current day's instruction, often continued to exert an influence on the focal students' situated composing practices for some time after the original lesson was completed. In this case, the students used a specific literacy practice from the nonfiction unit and transformed it to fit their new purposes when writing about the Titanic. This was an example of students engaging in transformed practice (New London Group, 2000), or using already learned literacy practices in new contexts and for new purposes. This showed that some elements from the lessons proved useful enough to be reused over time as reliable and flexible writing tools. When the students were given opportunities to use lessons in flexible and diverse ways, they transformed the writing tools that Ms. Stevens had provided, finding new uses for them in their more open-ended composing.

\section{Implications for Teaching}

Overt instruction and situated practice have often been cast as opposite teaching strands that are incompatible with each other in genre teaching. However, this case study reminded me that the compatibility of overt instruction with situated practice in genre teaching depends on how these elements are conceptualized. As I looked closely at this genre study, I was particularly struck by how Ms. Stevens's overt instruction was dependent upon its effective relation to situated practice. This resonates with the work of literacy scholars who have worked toward critical syntheses of ideas from these two teaching strands (Hicks, 1997; New London Group, 2000).

As Ms. Stevens implemented this genre study, she offered resources and tools for the students to use as they explored nonfiction on their own. She kept her lessons oriented toward the overall activities of writing informational books about animals so that the students could see the purpose and usefulness of the lessons. This is important because literacy scholars have pointed out that genres are not fixed entities but rather change over time and from context to context (Kress, 1993; Miller, 1994). For this reason, Dean (2008) noted that when teaching genres, "a key instructional principle must be keeping genre and contexts as connected as possible" (p. 30). This principle was visible in Ms. Stevens's teaching. She did not break her lessons into subcomponents that were not related to the purposes at hand (collaboratively composing books about animals). As a result, across this genre study, the students engaged in multifaceted and multipurposed uses of literacy. The use of diverse and multifaceted literacy practices is important for all students, including students learning English as an additional language or developing biliteracies (Pérez, 2004; Samway, 2006). Figure 6 lists some of the types of literacy practices and competencies that the students explored during the unit.

I have used the term overt instruction to describe the expert guidance that Ms. Stevens provided the students during the genre study. However, it is important to note that overt instruction is distinct from possible

\section{Figure 6 \\ Examples of Multifaceted Literacy Practices Explored During the Genre Study}

- Doing research

- Using a book as a source of information for research

- Verifying information

- Phrasing research findings in one's own writing voice

- Summarizing findings

- Constructing sentences

- Using conjunctions

- Reading with a specific purpose

- Ordering sentences

- Constructing/using a table of contents

- Collaborating on constructing a text

- Constructing/using an "about the author" page

- Titling texts

- Identifying and organizing themes in texts

- Writing in a nonfiction genre

- Using punctuation

- Using strategies for reading nonfiction 
connotations of other, similar, terms (e.g., direct or explicit teaching). Overt instruction is, according to the New London Group (2000), effectively coupled with situated practice. Another way of conceptualizing overt instruction in this context is to think of it as providing scaffolding to students as they write. Ms. Stevens's lessons provided literacy scaffolds (Boyle \& Peregoy, 1990) to the students alongside situated practice. Gibbons (2002), who has also taken up the question of genre teaching with students learning English as an additional language, discussed the role of scaffolding in a way that resonates with my discussion of overt instruction in this article. She noted,

It doesn't mean a return to the teaching of traditional grammar... Neither does it mean a breaking up of language into its component parts of speech, or a fragmentation of the timetable into spelling, dictation, composition, and so on, or a separation of the macroskills of reading, writing, listening, and speaking...understanding about language is developed in the context of actual language use. (p. 60)

In terms of teaching genres, overt instruction implies that students have access to instruction on what makes up a particular genre and ample opportunities to explore the genres themselves in a way that is attuned to students' interests and competencies. Situated practice, in essence, became the medium through which the students appropriated overt instruction into their everyday literacy practices. In this sense, giving students opportunities to purposefully and meaningfully use overt instruction is as important as providing useful lessons and guidance. Of course, not providing enough guidance or scaffolding to students as they compose in new genres and in an additional language may be problematic, because such expert guidance can give some students access to culturally valued literacy practices that they might not otherwise appropriate (Gibbons, 2002; Reyes, 1992). For students who are learning a genre as a new set of cultural practices, effective conceptualization of overt instruction in relation to situated practice is especially important.

Ms. Stevens's teaching provides a helpful example for considering this teaching question, but there are many complexities to be considered. It is important to note, for example, that the teaching question I have explored in this article has a specific history in the genre-teaching literature and cannot be applied equally to all curricular contexts or literacy learning situations. It is also important to note that overt instruction takes many forms (besides lessons, as I have focused on in this article), including writing conferences and guided writing groups. In addition, the interaction of overt instruction and situated practice plays out in many forms and is not solved by a simple equation of attempting to balance them in all situations. For example, Ms. Stevens's lessons were focused on the composing purposes at hand and did not unduly consume the extended time that she had designated for the students' situated practice with reading and writing nonfiction.

I would also like to note that, on most days, Ms. Stevens gave the students a broader range of choices in their subject matter and composing/reading decisions as they engaged in a more open-ended form of situated practice during the daily reading/writing workshop. This is important, because this gave students opportunities to draw upon a broader range of subjects, "funds of knowledge" (González, Moll, $\&$ Amanti, 2005), and linguistic resources related to their families, popular cultural interests, and lived/ imagined social worlds. When given open-ended writing tasks, students may explore multifaceted and diverse discourses that a teacher's lessons cannot anticipate. In this classroom, Ms. Stevens's periodic introduction of a focused genre study provided a thoughtful complement to her overall workshopbased literacy program. Her teaching provides a useful example for thinking about how to use the potentials of overt instruction and situated practice in genre teaching and learning.

\section{References}

Atwell, N. (1998). In the middle: New understandings about writing, reading, and learning. Portsmouth, $\mathrm{NH}$ : Heinemann.

Avery, C. (2002)....And with a light touch: Learning about reading, writing, and teaching with first graders (2nd ed.). Portsmouth, $\mathrm{NH}$ : Heinemann.

Boyle, O., \& Peregoy, S. (1990). Literacy scaffolds: Strategies for first- and second-language readers and writers. The Reading Teacher, 44(3), 194-200.

Calkins, L. (1994). The art of teaching writing (New ed.). Portsmouth, NH: Heinemann.

Christie, F. (1985). Writing in schools: Generic structures as ways of meaning. In B. Couture (Ed.), Functional approaches to writing: Research perspectives (pp. 221-240). London: Pinter.

Christie, F. (1999). Genre theory and ESL teaching: A systemic functional perspective. TESOL Quarterly, 33(4), 759-763. doi: $10.2307 / 3587889$

Cope, B., \& Kalantzis, M. (1993). The power of literacy and the literacy of power. In B. Cope \& M. Kalantzis (Eds.), The powers of literacy: A genre approach to teaching writing (pp. 63-89). Pittsburgh, PA: University of Pittsburgh Press. 
Dean, D. (2008). Genre theory: Teaching, writing, and being. Urbana, IL: National Council of Teachers of English.

Duke, N., \& Purcell-Gates, V. (2003). Genres at home and at school: Bridging the known to the new. The Reading Teacher, 57(1), 30-37. doi:10.1598/RT.57.1.4

Dyson, A.H., \& Genishi, C. (2005). On the case: Approaches to language and literacy research. New York: Teachers College Press.

Fu, D. (2003). An island of English: Teaching ESL in Chinatown. Portsmouth, NH: Heinemann.

Gibbons, P. (2002). Scaffolding language, scaffolding learning: Teaching second language learners in the mainstream classroom. Portsmouth, NH: Heinemann.

González, N., Moll, L., \& Amanti, C. (2005). Funds of knowledge: Theorizing practices in households, communities, and classrooms. Mahwah, NJ: Erlbaum.

Green, B. (1987). Gender, genre and writing pedagogy. In I. Reid (Ed.), The place of genre in learning: Current debates (pp. 8390). Melbourne, VIC, Australia: Deakin University Press.

Gutiérrez, K. (1992). A comparison of instructional contexts in writing process classrooms with Latino children. Education and Urban Society, 24(2), 244-262. doi:10.1177/ 0013124592024002006

Hicks, D. (1997). Working through discourse genres in school. Research in the Teaching of English, 31(4), 459-485.

Kress, G. (1993). Genre as a social process. In B. Cope \& M. Kalantzis (Eds.), The powers of literacy: A genre approach to teaching writing (pp. 22-37). Pittsburgh, PA: University of Pittsburgh Press.

Merriam, S. (1998). Qualitative research and case study applications in education. San Francisco: Jossey-Bass.

Miller, C. (1994). Genre as social action. In A. Freedman \& P. Medway (Eds.), Genre and the new rhetoric (pp. 23-42). London: Taylor \& Francis.

New London Group. (2000). A pedagogy of multiliteracies designing social futures. In B. Cope \& M. Kalantzis (Eds.), Multiliteracies: Literacy learning and the design of social futures (pp. 9-37). New York: Routledge.
Palmer, R., \& Stewart, R. (2005). Models for using nonfiction in the primary grades. The Reading Teacher, 58(5), 426-434. doi:10.1598/RT.58.5.2

Pérez, B. (2004). Becoming biliterate: A study of two-way bilingual immersion education. Mahwah, NJ: Erlbaum.

Read, S. (2005). First and second graders writing informational text. The Reading Teacher, 59(1), 36-44. doi:10.1598/RT.59.1.4

Reyes, M. de la Luz. (1992). Challenging venerable assumptions: Literacy instruction for linguistically different students. Harvard Educational Review, 62(4), 427-446.

Samway, K. (2006). When English language learners write: Connecting research to practice, $K-8$. Portsmouth, $\mathrm{NH}$ : Heinemann.

Sawyer, W., \& Watson, K. (1989, December). Further questions on genre. English in Australia, 90, 27-42.

Taberski, S. (2000). On solid ground: Strategies for teaching reading $K-3$. Portsmouth, $\mathrm{NH}$ : Heinemann.

Vygotsky, L.S. (1978). Mind in society: The development of higher psychological processes (M. Cole, V. John-Steiner, S. Scribner, \& E. Souberman, Eds. \& Trans.). Cambridge, MA: Harvard University Press.

Wood, D., Bruner, J., \& Ross, G. (1976). The role of tutoring in problem solving. Journal of Child Psychology and Psychiatry, and Allied Disciplines, 17(2), 89-100. doi:10.1111/j.1469-7610.1976 .tb00381.x

\section{Literature Cited}

Arnosky, J. (2002). All about frogs. New York: Scholastic.

Betz, A. (2005). Sharks! Time for kids science scoops. New York: HarperTrophy.

Marschall, K. (1997). Inside the Titanic. New York: Little, Brown.

Stille, D. (2005). I am a shark: The story of a hammerhead shark. Minneapolis, MN: Picture Window.

Vern, A. (2001). Where do frogs come from? San Diego, CA: Harcourt.

Ranker teaches at Portland State University, Oregon, USA; e-mail jranker@pdx.edu. 